\title{
International Conference for the Protection of the Fauna and Flora of Africa
}

$\mathrm{T}$ HE Second International Conference for the Protection of the Fauna and Flora of Africa was opened by the Marquis of Dufferin and Ava, Parliamentary Under-Secretary of State for the Colonies, in the Moses Room of the House of Lords on May 24 and was attended by Government delegates of the Union of South Africa, Belgium, Great Britain and Northern Ireland, Egypt, France, Italy, Portugal and the Netherlands. The interests of the Anglo-Egyptian Sudan were represented by the United Kingdom and Egyptian delegations jointly. The main object of the Conference was the exchange of information and exploratory discussion preparatory to a further conference, which it is hoped to hold in 1939. The Earl of Onslow presided, and subsequent meetings were held on May 25 and 27. A committee of experts was appointed to draw up a list of suggestions for addition of further species to the Annex of the Convention.

It was announced that the Convention, signed in 1933, had been ratified by the United Kingdom and Belgium in respect of their African territories, and by the Union of South Africa, Egypt and the Sudan, and that it was hoped that France, Italy and Portugal would shortly be able to complete their ratifications. During the course of the meeting, the French delegate announced that he had just received information that the President of the French Republic was at that moment on the point of signing the ratification of France.

The proceedings opened by the submission of statements by delegates of action taken by their respective Governments since the signing of the Convention of 1933. The High Commissioner, Mr. C. T. te Water, on behalf of South Africa,.stressed the necessity of arousing public interest and stimulating effort for the protection of wild life, and pointed out that international conferences such as the present one help greatly in bringing to the attention of the Governments concerned a subject of great national importance. He stated that his Government is continuing its policy of setting aside areas as game reserves and national parks, and since the Convention had come into force, further legislation has been promulgated for the preservation of fauna and flora. $\mathrm{He}$ alluded to the serious condition of the status of the mountain zebra (Hippotogris zebra), which is slowly dying out, and said that the matter is being given close consideration by the Government in order to secure measures for the adequate protection of the remaining herds, and that land is being acquired in various districts to this end. $\mathrm{He}$ also mentioned that the laws with regard to shooting game from motor-vehicles are very strictly carried out.

The Belgian delegation reported the creation of further national parks and stated that an important feature of the administration of these parks is the undertaking of systematic exploration of their fauna and flora, with special reference to the presence of disease, particularly parasitic disease, among the animals contained therein. The Government has taken measures for the protection of flora by setting up forest reserves in which special attention is given to the need for maintaining an adequate water supply.
Sir William Gowers, Senior Crown Agent for the Colonies, in presenting the report of the United Kingdom, directed attention to the great diversity of conditions in the fourteen territories concerned, and their difference in range of flora, fauna and density of population. The establishment of reserves is the policy of many Governments, but, while it is not regarded as incompatible with the principles of the Convention that a national park should be inhabited by natives, it is nevertheless regarded as important that the extent of native population should not be such as to interfere on one hand with the rights of the natives and on the other with the interests of game preservation. It has therefore been necessary to proceed with caution before definitely demarcating areas to be set aside as national parks. In pointing out the salient features of the report, Sir William Gowers mentioned the action being taken by the Tanganyika Government in establishing a national park on the Serengeti Plains, the steps taken by the Govermment of Nyasaland to set up a strict natural reserve in its territory, and the proposals under consideration for similar measures in Kenya, Nigeria and Sierra Leone.

Mr. F. B. Wright, Acting High Commissioner for Southern Rhodesia, reported the establishment of four game reserves and emphasized the interest felt by his Government for the objects of the Convention.

The Italian delegate stated that a special scientific mission has been sent to Italian East Africa to undertake a full survey of the position with regard to fauna and flora, and that the results of this investigation will be communicated for circulation.

The Portuguese delegate in presenting his report put forward two suggestions ; first, that the question of surrounding animals by fire for hunting purposes should be examined again on account of the harm which this causes to fauna and flora; and secondly, that the possibility of taking measures for the partial and progressive modification of nomad native agriculture in African forests, in order to avoid the frequent and irregular clearing of important tracts of forest land, should be considered.

Statements were also given by the Egyptian, French and Anglo-Egyptian Sudan representatives, and the Netherlands delegate stated that his Government is greatly in favour of the Convention and has already applied Article 9 (concerning the traffic in 'trophies') to the Dutch East Indies.

A discussion on the subject of vermin took place and it was agreed that a positive definition of this is impracticable. Mr. te Water suggested that all Governments concerned be asked to furnish memo. randa showing action taken in their respective territories to deal with this problem.

The question of $(a)$ the exchange of information relating to infectious or contagious diseases of importance for the preservation of fauna or flora, or capable of affecting man as well as animals and, (b) the exchange between Governments of lists of persons known to have been guilty of persistent infringements of game regulations, were both examined at length, and the conclusion reached that with regard to both these questions a centralized system of exchange of 
information is desirable, and that recommendations to this end should be put forward.

The report submitted by the Committee of Experts as to species recommended for inclusion in the Annex of the Convention on the occasion of its next revision was accepted. This contained proposals for the transference of certain species mentioned in the Annex from Class $B$ to Class $A$, thereby affording them greater protection, and included among others the giant eland (Taurotragus derbianus (Gray)), black rhinoceros (Rhinoceros bicornis Linnæus) and secretary bird (Sagittarius serpentarius serpentarius Miller). The report also suggested the inclusion in both classes of certain species not heretofore included in the Annex. For inclusion in Class $A$ were recommended among others the red wolf (Canis simensis (Ruppell)) and bongo (Boocercus eurycerus Ogilby) and the African peacock (Afropava congensis Chapin), so recently discovered to science, northern secretary bird (Sagittarius serpentarius gambiensus Ogilby), African broadbill (Pseudocalyptomena graueri Rothschild), Abysinnian ground chough (Zavattariornis stresemanni Holtoni), the flightless rail of Inaccessible Island (Atlantisia rogersi Lowe) and the so-called fishes of the grottoes of Thysville, African species of the genus Caccobarbus. The last-named was the only case for the protection of fish brought to the attention of the Committee. The species being blind and of great zoological interest, it is the opinion of the Committee that it should receive as complete protection as possible.

The Conference agreed to recommend that a further meeting be held in London in 1939, concurrently with the meeting of the proposed International Conference for the Protection of Fauna and Flora of Tropical Asia and the Western Pacific. On the proposal of Mr. te Water, it was agreed to express the hope that it would be possible for the Governments concerned to arrange for the attachment to their respective delegations of officers in charge of the principal national parks, such as the Kruger National Park, and the Parc National Albert, whose expert advice would greatly assist the work of the Conference.

\section{Impact of Chemistry on Biology}

$\mathrm{T}$ HE forty-second Bedson Lecture was delivered in the Chemistry Lecture Theatre, King's College, Newcastle-on-Tyne, on May 19 by Sir Henry Dale, who spoke on "The Impact of Chemistry on Biological Science". Sir Henry pointed out that the two sciences of biology and chemistry were developed during the nineteenth century independently of each other; tremendous advances have been made in more recent times as the two subjects have become closely interwoven into the science of biochemistry.

Since the end of the last century, organic chemistry has developed along two main lines: (1) the synthesis of new substances of little direct relation to biological science, and (2) the isolation and identification of substances from 'vital' chemistry. Progress has been slow in the chemistry of the animal body, and the lag between chemical recognition and the assignment of a definite biological function to compounds isolated is well exemplified by the fact that although creatine was isolated from muscle in 1832, it was not until 1927 that a definite role in muscle metabolism was assigned to this substance.

The comparatively new science of bacteriology had its origin in the work of Louis Pasteur, an organic chemist whose interests developed along 'biochemical' lines until he eventually became a complete biologist.
The investigation of protein chemistry by Sir Frederick Gowland Hopkins which led to his attempt to make a 'perfect' diet by mixing the correct amounts of fats, carbohydrates and proteins gave rise to one of the most sensational discoveries in recent years, the vitamins. In a very short time, many of these compounds have been not only isolated, but also in some cases have been assigned a definite chemical formula which has been proved by synthesis.

Several enzyme actions have recently been in. vestigated from a chemical point of view, and it seems extremely probable that enzyme and coenzyme phenomena will shortly be explained as chemical actions, closely.connected in some cases with the vitamins.

The discovery of the natural stimulants formed by the animal body, the hormones, has opened up an important new field of biochemical research, in which great advances have already been made. Several of these compounds have been isolated and synthesized, such as, for example, thyroxin and adrenaline, and the sex hormones have been shown by synthesis to be closely connected with inert sterols present in animal tissues.

Finally, even the transmission of nerve 'messages' has been shown to involve reversible physicochemical changes in which simple organic compounds play a part.

\section{Pre-Roman Provence}

$\mathrm{E}^{\mathrm{A}}$ ARLY in April of this year, it was announced that archæological discoveries, which are of no little importance, had been made near Saint-Rémy, a small town a few miles from Arles in Provence. Provence, the original 'Provincia' of Rome's extraItalian expansion, is rich in monuments, which, if Roman in origin, are none the less Greek in spirit and conception. This is a legacy from the Greek colonists from Phocaea, who founded Marseilles about 600 B.c. and extended their influence over the whole region, which was later to be known as "The Province". Intermarriage with the natives left an indelible mark on the physique of the population, more especially to be seen in the beauty of the Provençal women.

Although the district around Arles was termed "Grecia" until the fourteenth century, little is known that is of purely Greek culture, nor has it been determined with precision how far and to what degree Greek influence pervaded the country. The importance 